\title{
Beluga whale stewardship and collaborative research practices among Indigenous peoples in the Arctic
} \author{
Joseph Townley ${ }^{4}$ \& Eduard Zdor ${ }^{12}$ \\ ${ }^{1}$ Nunavik Marine Region Wildlife Board, Inukjuak, QC, Canada \\ 2Ocean Conservancy, Eagle River, AK, USA \\ ${ }^{3}$ Fisheries Joint Management Committee, Inuvik, NT, Canada \\ ${ }^{4}$ Department of Lands and Natural Resources, Nunatsiavut Government, Nain, NL, Canada \\ ${ }^{5}$ Alaska Beluga Whale Committee, Nome, AK, USA \\ ${ }^{6}$ Oceans North Greenland, Nuuk, Greenland \\ ${ }^{7}$ Department of Wildlife and Environment, Nunavut Tunngavik Inc., Ottawa, ON, Canada \\ ${ }^{8}$ Freshwater Institute, Fisheries and Oceans Canada, Winnipeg, MB, Canada \\ 'Environment and Geography, University of Winnipeg, Winnipeg, MB, Canada \\ ${ }^{10}$ Inuvialuit Game Council, Paulatuk, NT, Canada \\ ${ }^{11}$ Kivalliq Wildlife Board, Nunavut Inuit Wildlife Secretariat, Rankin Inlet, NU, Canada \\ ${ }^{12}$ University of Alaska Fairbanks, Fairbanks, AK, USA
}

Kaitlin Breton-Honeyman', Henry P. Huntington², Mark Basterfield', Kiyo Campbell ${ }^{3}$, Jason Dicker ${ }^{4}$, Tom Gray ${ }^{5}$, Alfred E.R. Jakobsen ${ }^{6}$, Frankie Jean-Gagnon ${ }^{1}$, David Lee ${ }^{7}$, Rodd Laing ${ }^{4}$, Lisa Loseto ${ }^{8,9}$, Paul McCarney ${ }^{4}$, John Noksana Jr. ${ }^{3}$, Tommy Palliser ${ }^{1}$, Lawrence Ruben ${ }^{10}$, Clayton Tartak ${ }^{11}$,

\begin{abstract}
Beluga whales (Delphinapterus leucas) are an integral part of many Arctic Indigenous cultures and contribute to food security for communities from Greenland, across northern Canada and Alaska to Chukotka, Russia. Although the harvesting and stewardship practices of Indigenous peoples vary among regions and have shifted and adapted over time, central principles of respect for beluga and sharing of the harvest have remained steadfast. In addition to intra-community cooperation to harvest, process and use beluga whales, rapid environmental change in the Arctic has underscored the need for inter-regional communication as well as collaboration with scientists and managers to sustain beluga populations and their cultural and nutritional roles in Arctic communities. Our paper, written by the overlapping categories of researchers, hunters, and managers, first provides an overview of beluga hunting and collaborative research in seven regions of the Arctic (Greenland; Nunatsiavut, Nunavik, Nunavut, and the Inuvialuit Settlement Region, Canada; Alaska; and Chukotka). Then we present a more detailed case study of collaboration, examining a recent research and management project that utilizes co-production of knowledge to address the conservation of a depleted population of beluga in Nunavik, Canada. We conclude that sustaining traditional values, establishing collaborative management efforts, the equitable inclusion of Indigenous Knowledge, and respectful and meaningful collaborations among hunters, researchers and managers are essential to sustaining healthy beluga populations and the peoples who live with and depend upon them in a time of rapid social and environmental change.
\end{abstract}

\section{Keywords}

marine mammals; Arctic; co-production of knowledge; wildlife research and management; Delphinapterus leucas

\section{Correspondence}

K. Breton-Honeyman, Nunavik Marine Region Wildlife Board, PO Box 433, Inukjuak, J0M $1 \mathrm{MO}$ QC, Canada. E-mail:

kbretonhoneyman@polynyaconsulting.ca

\section{Abbreviations}

COSEWIC: Committee on the Status of Endangered Wildlife in Canada

DFO: Fisheries and Oceans Canada EHB: eastern Hudson Bay

FJMC: Fisheries Joint Management Committee

NILCA: Nunavik Inuit Land Claims Agreement NMRWB: Nunavik Marine Region Wildlife Board

TAT: total allowable take

WHB: western Hudson Bay

This article is part of the special cluster Beluga whales (Delphinapterus leucas): knowledge from the wild, human care and TEK, which has been funded by Mystic Aquarium, CAFF and the Norwegian Ministry of Climate and Environment.

\section{Introduction}

The beluga whale (Delphinapterus leucas) is found throughout the Arctic and in some Subarctic locations (Hobbs et al. 2019; Fig. 1). Indigenous peoples in Greenland,
Canada, Alaska and Chukotka (Russia) regularly hunt beluga (Meehan et al. 2017), a practice that has continued for centuries or longer, effectively since time immemorial (e.g., Lucier \& VanStone 1995). The role of beluga varies by community, from occasional part of the diet to 


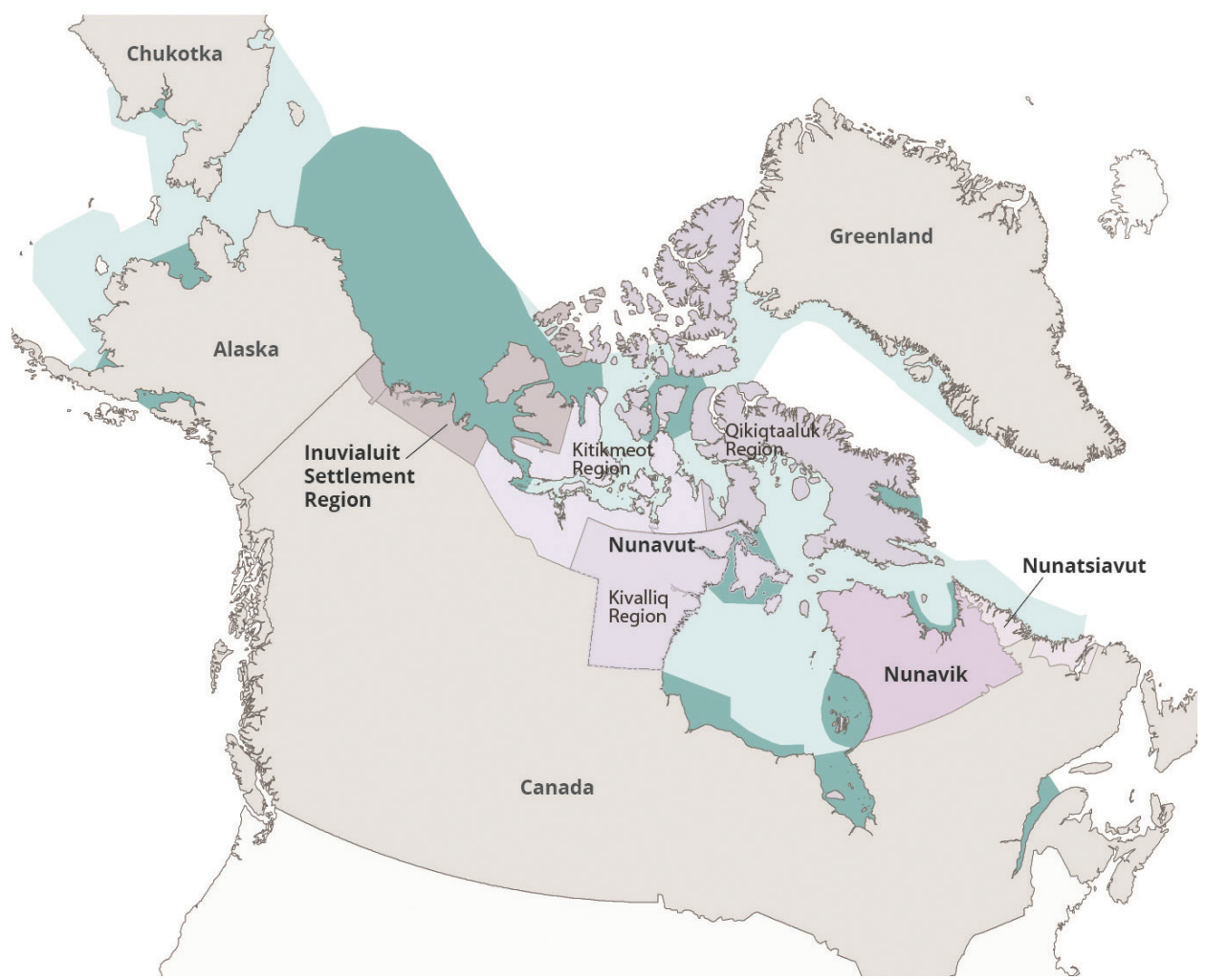

Fig. 1. Seven regions of the Arctic where Indigenous peoples harvest beluga (Greenland; Nunatsiavut, Nunavik, Nunavut, and the Inuvialuit Settlement Region, Canada; Alaska; and Chukotka) and beluga distribution for summering areas (dark blue-green), and wintering and migratory areas (light blue-green) (Hobbs et al. 2019).

the majority of the annual harvest of traditional foods (Blanchet \& Rochette 2008; Frost \& Suydam 2010; Kenny $\varepsilon$ Chan 2017; NAMMCO 2018). Beluga are also a popular symbol of the Arctic and studied throughout their range (NAMMCO 2018). The convergence of traditional practice in Indigenous communities, assertion of Indigenous harvesting and land rights, and widespread interest by the public, academia and government has given rise to collaborative management efforts (in some contexts formal co-management arrangements) in many regions. Through such efforts, hunters, researchers, Elders, and management officials work together to conserve beluga whale populations and sustain traditional harvests (Table 1).

In this paper, whose authors are researchers, hunters, wildlife managers, or a combination thereof, we review Indigenous stewardship practices and collaborative research efforts regarding beluga whales in the regions where these animals are hunted regularly. The two themes emerged from panel discussions at the Second International Workshop on Beluga Whale Research and Conservation, held in Mystic, CT, in March 2019. Specifically, Indigenous participants spoke about the continuing importance of beluga hunting for Indigenous
Table 1. Approximate average annual beluga harvest by region in recent years (ca. five years). There is considerable inter-annual variability in some regions. (Frost \& Suydam 2010; NAMMCO 2018; Hobbs et al. 2019; DFO unpubl. data; Alaska Beluga Whale Committee unpubl. data).

\begin{tabular}{|c|c|c|}
\hline Region & $\begin{array}{c}\text { Approximate } \\
\text { annual harvest }\end{array}$ & Stocks harvested from \\
\hline Greenland & 200 & Eastern High Arctic-Baffin Bay \\
\hline Nunatsiavut & $<5$ & $\begin{array}{l}\text { Unknown, possibly EHB or Cum- } \\
\text { berland Sound }\end{array}$ \\
\hline Nunavik & 300 & $\begin{array}{l}\text { EHB (65) } \\
\text { James Bay (10) } \\
\text { WHB (250) } \\
\text { Ungava Bay (few if any) }\end{array}$ \\
\hline Nunavut & 400 & $\begin{array}{l}\text { Cumberland Sound } \\
\text { Eastern High Arctic-Baffin Bay } \\
\text { EHB } \\
\text { WHB }\end{array}$ \\
\hline $\begin{array}{l}\text { Inuvialuit Settlement } \\
\text { Region }\end{array}$ & 90 & Eastern Beaufort Sea \\
\hline Alaska & 300 & $\begin{array}{l}\text { Bristol Bay (20) } \\
\text { Eastern Beaufort Sea (40) } \\
\text { Eastern Bering Sea (190) } \\
\text { Eastern Chukchi Sea (60) }\end{array}$ \\
\hline Chukotka & 20 & $\begin{array}{l}\text { Anadyr (2) } \\
\text { Eastern Bering Sea (20) }\end{array}$ \\
\hline
\end{tabular}


identity and community well-being ("If you share your catch, your freezer will always be full"), and about the necessity in changing times of hunters working with scientists and managers to achieve what none can achieve alone ("We will need help").

The review begins with overviews from Greenland; Nunatsiavut, Nunavik, Nunavut, and the Inuvialuit Settlement Region in Canada; Alaska; and Chukotka, Russia. The descriptions, by authors from each region, are based on extensive personal involvement in beluga hunting, research and management, supplemented by published literature where available. Then, we take a closer look at beluga hunting and management in Nunavik, Canada, site of particularly entangled conservation concerns rooted in historical commercial harvesting and complicated by overlapping beluga populations with different conservation statuses. The Nunavik case study was prepared by individuals affiliated with the NMRWB, who have had direct experience with all aspects of beluga whales in that region. We conclude with a discussion of the significance of beluga whale stewardship and research.

While many of these topics have been addressed in numerous publications about different locales in the Arctic, we are unaware of any recent effort to compile in one place the available information on beluga stewardship and collaborative research across the Arctic region of Indigenous beluga hunting. We believe there is much to learn from sharing experiences across regions and hope that our paper furthers self-determination in beluga stewardship and the persistence of harvesting practices and healthy beluga populations.

\section{Regional harvest practices, traditional values and collaborations}

Many regions share a similar history of hunting beluga quietly by groups in kayaks without the use of rifles (e.g., Alayco et al. 2007). The sections below focus on more recent practices. Although Inuit and Chukchi have adopted modern tools, such as rifles and motorized boats, they continue to hunt beluga whales with traditional technology such as the unaaq (the Inuktitut term for the specialized beluga harpoon head and harpoon), which is attached to an avataq (float). The float not only slows the progress of the whale that can then be dispatched readily and humanely, but also permits retrieval of the whale, reducing the incidence of struck and lost whales. The regional overviews also discuss the degree to which beluga research is collaborative, giving examples of studies done through partnerships between Indigenous communities and visiting researchers and managers. One noteworthy trend is the growing intellectual role of
Indigenous individuals as initiators and leaders of research efforts. Table 2 provides a summary of the regional patterns. In these summaries, the contributors from each region have chosen what to emphasize, the Indigenous terminology to include and how to describe hunting and research in their areas. As a result, a strict consistency among regional descriptions has taken second place to local authenticity and perspectives.

\section{Greenland}

Beluga whales (qilalugaq qaqortoq) are hunted in Greenland, from the Baffin Bay stock of beluga shared with Canada (NAMMCO 2018). The beluga harvest has varied in recent years from the low hundreds to a little above 300 animals. Most are taken in west Greenland, though some are hunted in Qaanaaq and surrounding settlements in the north, including 105 taken in that region in 2019. Hunting occurs in spring, summer and fall, from small boats or from the ice. In Qaanaaq in particular, some hunting is done from kayaks or with nets (NAMMCO 2021). Current harvest levels are regarded as sustainable (Heide-Jørgensen et al. 2017); concerns about overhunting in the 1990s led to management efforts aimed at reducing the harvest to sustainable levels, including the introduction of overall quotas in 2004. The harvest has also been reduced because beluga are less available to hunters now that climate change has shifted the ice edge-the preferred habitat of the animals when they migrate to Greenland in winter-farther from shore (Heide-Jørgensen et al. 2017). One result of the smaller harvest and changes in hunting practices has been that sharing practices have shifted to emphasize participation in the hunt rather than specific roles or actions; this is built on egalitarian principles but rewards larger boats with more participants (Sejersen 2001). A further societal challenge is competition among 'professional' and 'non-professional' hunters regarding the allocation of the harvest quota, which may cause resentment and undermine the perceived legitimacy of the management system.

Beluga research in Greenland has included aerial surveys (Heide-Jørgensen et al. 2010), genetic analysis (Palsbøll et al. 2002) and satellite telemetry (Richard et al. 2001). Hunters have contributed samples for analysis (NAMMCO 2021). Thomsen (1993) documented knowledge from Inuit hunters in western and northern Greenland. Hunters provide the government with detailed reports that include, for each catch, date and position, information about the hunting method and biological data such as age class, gender, size, reproductive state and stomach contents. This information is used in the assessments by the North Atlantic Marine Mammal Commission and the Canada-Greenland Joint Commission on Narwhal and Beluga (Meehan et al. 2017). Other than this, there has 
Table 2. Traditional values, hunting and stewardship practice, management organization and approach and collaboration by region.

\begin{tabular}{|c|c|c|c|c|}
\hline Region & Traditional values & Hunting and stewardship practices & Management body & Collaboration ${ }^{a}$ \\
\hline \multirow[t]{2}{*}{ Greenland } & Sharing & \multirow{2}{*}{$\begin{array}{l}\text { Harvesting from small boats or ice (kay- } \\
\text { aks or nets in Qaanaaq) }\end{array}$} & \multirow{2}{*}{$\begin{array}{l}\text { Greenland Self-Rule } \\
\text { Government }\end{array}$} & + \\
\hline & Respect & & & Harvest sampling \\
\hline \multirow[t]{3}{*}{ Nunatsiavut } & Sharing & \multirow{3}{*}{$\begin{array}{l}\text { Harvesting from shore, boat, or sina } \\
\text { (floe edge) depending on the season }\end{array}$} & \multirow[t]{3}{*}{ DFO } & ++ \\
\hline & Respect & & & Few research projects but \\
\hline & & & & most collaborative \\
\hline \multirow[t]{6}{*}{ Nunavik } & Sharing of catch & \multirow{2}{*}{$\begin{array}{l}\text { Harvesting from shore or boat depend- } \\
\text { ing on the season }\end{array}$} & \multirow[t]{6}{*}{ NMRWB: co-management } & ++ \\
\hline & Respect & & & Harvest sampling and \\
\hline & Taking only what is needed & Use of rifles, harpoons and heavy hooks & & some research projects \\
\hline & \multirow[t]{3}{*}{ Avoiding wastage and noise } & Kayaks historically & & \\
\hline & & Avoiding harvest of lead whales & & \\
\hline & & Estuary closures & & \\
\hline \multirow[t]{6}{*}{ Nunavut } & Inuit Qaujimajatuqangit & Harvest in the fall (Kivalliq Region) & \multirow{6}{*}{$\begin{array}{l}\text { Nunavut Wildife } \\
\text { Management Board: } \\
\text { co-management }\end{array}$} & ++ \\
\hline & Respect & Closed harvest season in summer (EHB) & & New community-based \\
\hline & Taking only what is needed & Total Allowable Harvest (Cumberland & & research projects \\
\hline & \multirow[t]{3}{*}{ Sharing } & Sound) & & \\
\hline & & $\begin{array}{l}\text { Motor boats, high-powered rifles, unaaq } \\
\text { and avataq (harpoon with float) }\end{array}$ & & \\
\hline & & Kayaks historically & & \\
\hline \multirow{5}{*}{$\begin{array}{l}\text { Inuvialuit Settle- } \\
\text { ment Region }\end{array}$} & \multirow{5}{*}{$\begin{array}{l}\text { Respect for beluga } \\
\text { Sharing of catch } \\
\text { Cooperation }\end{array}$} & Hunting from small boats & \multirow{5}{*}{$\begin{array}{l}\text { FJMC, Inuvialuit Game } \\
\text { Council: co-management }\end{array}$} & +++ \\
\hline & & Harpoon first & & Hunters involved in all \\
\hline & & Avoid harvesting females & & current research projects \\
\hline & & Community hunting by-laws & & More work on Indigenous \\
\hline & & co-management & & \\
\hline \multirow[t]{6}{*}{ Alaska } & Prohibition on waste & Harvesting from shorefast ice (spring) & \multirow{6}{*}{$\begin{array}{l}\text { Alaska Beluga Whale Com- } \\
\text { mittee: co-management }\end{array}$} & +++ \\
\hline & Respect for whales & Harvesting by boat (summer and fall) & & Hunters involved in many \\
\hline & Sharing of catch & Netting from shore (summer and fall) & & research projects \\
\hline & Preparation for hunt & \multirow[t]{3}{*}{ Harpoon and rifles } & & Hunters involved in iden- \\
\hline & Conflict avoidance & & & $\begin{array}{l}\text { tifying research priorities } \\
\text { through the Alaska Beluga }\end{array}$ \\
\hline & Reduction of struck and lost & & & Whale Committee \\
\hline \multirow[t]{8}{*}{ Chukotka } & \multirow{8}{*}{$\begin{array}{l}\text { Catch distributed among } \\
\text { hunters and neighbours }\end{array}$} & \multirow{8}{*}{$\begin{array}{l}\text { Mainly spring and late fall } \\
\text { Usually from shore (summer) or shore- } \\
\text { fast ice (winter) } \\
\text { Rifle, harpoon and wooden or metal } \\
\text { hook } \\
\text { Head returned to the sea }\end{array}$} & \multirow{3}{*}{$\begin{array}{l}\text { Federal government (gen- } \\
\text { eral permit for hunting by } \\
\text { the Indigenous peoples of } \\
\text { Chukotka) }\end{array}$} & + \\
\hline & & & & Some research projects, \\
\hline & & & & including biopsy sampling \\
\hline & & & The Chukotka Fisheries & \\
\hline & & & Commission (government & \\
\hline & & & of the Chukotka Okrug) & \\
\hline & & & allocates the quota among & \\
\hline & & & villages. & \\
\hline
\end{tabular}

a little collaboration, ++ moderate collaboration, +++ extensive collaboration. 
been little collaborative research involving hunters and scientists compared with Canada and Alaska.

\section{Nunatsiavut, Canada}

Labrador Inuit in Nunatsiavut have traditionally hunted beluga (kilalugak) seasonally when whales came to the Labrador coast. There is extensive reference to Labrador Inuit hunting various species of whales throughout the 17 th and 18th centuries, including 'white whales' (BriceBennett 1977). Brice-Bennett (1977) mapped core areas of beluga in a number of areas throughout the outer islands along the Labrador coast from the Hopedale region to Nachvak Fjord. Brice-Bennett also describes that on the northward migration of beluga, during spring when the landfast ice began break-up, "[e]very year, the hunters shot a few white whales while waiting along the floe edge for seals. They had to harpoon the whales quickly before they sank, then haul them up on the ice, where they shared their meat and skin" (1977: 121). Inuit also hunted beluga during June and July in Hebron, Saglek and Nachvak fjords during calving and feeding times. Taylor (1977) describes traditional historical seasonal movement patterns of Labrador Inuit. In spring, typically from mid-April to late June, historical records show that "[i]n several areas, walrus and white whales were also important. White whales were particularly important at Avertok, Kivertlok, Kangerdluksoak, and Naghvakh" (1977: 53). Taylor \& Taylor (1977) describe spring and summer hunting of beluga in the Okak region between 1776 and 1830 .

At present, beluga are not abundant around the five Nunatsiavut communities (Nain, Hopedale, Postville, Makkovik and Rigolet). Few people in Nunatsiavut actively and deliberately hunt beluga today and beluga do not form a large component of the Labrador Inuit wild food diet. Changes in sea-ice conditions make it more difficult to hunt beluga during the spring season, when whales begin to arrive. During ice conditions that are likely favourable, Inuit try to harvest beluga, most commonly in the Hopedale region. Beluga hunting remains a communal and social activity. Hunters in Nain and Hopedale explain that some people still hunt beluga in larger groups while others go out in smaller groups of one or two other people. It is still a common practice to share the catch with the whole community after a successful hunt. People come to the water when a whale is brought in to take meat and blubber for their households. All Nunatsiavut communities currently have community freezers that distribute wild meat to community members. When hunters have taken their share of a harvested beluga, the rest is delivered to the community freezer to share with the rest of the community.
Beluga numbers decreased along the Labrador coast in the early 1900s, and by 1920 it was considered rare to see a beluga south of the Torngat region (Brice-Bennett 1978). DFO records of beluga within the study area covered by McCarney et al. (2021) include a total of nine individuals and an additional single individual within $20 \mathrm{~km}$ of the study area in recent years. However, the low number of systematic surveys over time make it difficult to assess population trends. Genetics research has been conducted in collaboration between DFO and the Nunatsiavut Government, with analysis ongoing (J. Lawson, DFO, unpubl. data). Samples for genetics analysis were provided by the Nunatsiavut Government. There is evidence to suggest that some of the beluga found along the Labrador coast belong to the EHB population. Telemetry work identified the Hopedale Saddle Ecologically and Biologically Significant Area as an important overwintering habitat for EHB beluga (Lewis et al. 2009; Bailleul et al. 2012a). The Northern Labrador Ecologically and Biologically Significant Area has also been identified as a unique migratory area for EHB beluga (DFO 2013).

\section{Nunavik, Canada}

All 14 Nunavik communities harvest beluga (qilalugaq). Beluga from four different summering groups-WHB, EHB, Ungava Bay (where few beluga remain) and James Bay-are locally accessible to communities at different times of the year and with varying abundance; however, many communities have to travel to access larger groups of beluga. Hunting predominantly occurs along the spring and fall migratory routes of the WHB and EHB beluga. During the summer, harvest rates decline in most of Nunavik, with the exception of south-eastern Hudson Bay which is the summering area for the EHB stock. However, management restrictions and other factors keep harvest levels in this area relatively low. In areas where beluga travel close to the shore, hunting often takes place from the ice (in spring) or the shore (in fall) with the assistance of boats, harpoons and heavy hooks to retrieve whales. Boats are commonly used in areas where beluga occur further offshore and during the summer.

At present, the hunting method is to harpoon first, followed by the use of a rifle, with rare exceptions (e.g., in some areas beluga float in the spring and the water is shallow and clear, making the use of a harpoon unnecessary). Regardless of the hunting method, practices such as sharing the catch, showing respect for the whale, not taking more than is needed and avoiding wastage govern beluga harvesting in all communities (Alayco et al. 2007; Tyrrell 2008). Beluga are sensitive to noise, so traditional hunting practices also avoid noise disturbance. Other practices, such as avoiding harvesting the lead whales 
during migration and avoiding females with calves, are followed by some hunters but management regulations and concerns over missed harvesting opportunities have altered some of these practices.

Beluga harvesting and management has a difficult history in Nunavik. Harvest quotas and other management measures were introduced in the 1980s in an effort to conserve EHB beluga (Hammill et al. 2004). However, these management regulations were viewed by many Nunavik Inuit as forms of cultural imperialism, imposed from outside the region (Tyrrell 2008) and widespread dissatisfaction remains. Despite these issues, there is a long-standing and successful harvest sampling programme whereby hunters send samples to the regional research centre for studies such as population dynamics, diet, contaminants and genetics. Aerial surveys, which have been repeatedly conducted since the 1980s (e.g., Gosselin et al. 2017), together with genetics research, form the foundation of the current management model (Turgeon et al. 2012; Mosnier et al. 2017). A satellite tagging programme was conducted for only a limited amount of time (Bailleul et al. $2012 b)$, as many hunters are opposed to that method. No tagging has occurred in the region since 2004. Several studies have documented Inuit knowledge, which has been increasingly incorporated into management approaches and measures (Doidge et al. 2002; Lee et al. 2002; Tyrrell 2007a; Lewis et al. 2009; Breton-Honeyman, Hammill et al. 2016). The formalization of co-management with the creation of NILCA, which established the NMRWB, has fostered further collaborative and community driven research efforts (e.g., a biopsy programme, observational research in estuaries), including research that has supported the health benefits of consuming beluga (Lemire et al. 2015; Little et al. 2019).

\section{Nunavut, Canada}

Beluga (qilalugaq/qinalugaq) are found in most of Nunavut waters. Communities in Nunavut harvest primarily from four stocks: Cumberland Sound, Eastern High Arctic-Baffin Bay, EHB and WHB. With a population estimate of about 54 500 , the WHB beluga stock is one of the world's largest (Matthews et al. 2017). In the Kivalliq Region, communities regularly hunt beluga whereas communities in the east Kitikmeot Region often travel farther distances from the community to hunt beluga. Beluga are not observed with regular frequency in west Kitikmeot. In the Qiqiktaaluk Region, beluga are hunted regularly from many communities. The hunting of beluga whales (Qinalugaqsiurniq) in the Kivalliq Region typically commences in early fall (ukiaksaaq), as beluga migrate north along the WHB coast (Colbeck et al. 2013). Hunters generally wait until whales have finished moulting, which occurs in estuaries such as those of the Seal, Churchill and Nelson rivers (St. Aubin et al. 1990; Smith et al. 2017). Inuit rapidly transitioned to motor-powered boats and high-powered rifles as the technology became available but they also retain many of traditional practices and equipment.

Traditional practices govern the management of most of the stocks in Nunavut; however, for the Cumberland Sound beluga stock, which was decimated by commercial whalers and the Hudson Bay Company between 1868 and 1939, quotas were enacted by the federal government in amendments to the Beluga and Narwhal Protection Regulations in 1980 and 1990 (Stevenson 1997; Kilabuk 1998; Stewart 2018). The establishment of the quotas has contributed to a long-conflicted relationship between DFO and the community of Pangnirtung (Richard \& Pike 1991). Inuit continue to say that their knowledge has not been valued or applied in management decision-making (Freeman et al. 1998). DFO and the community representatives have recently established another working group to co-develop a management plan for this stock, which is intended to include the compilation, mobilization and application of Inuit knowledge.

Beluga remain economically, nutritionally and culturally important (Freeman 1993; Wein et al. 1996; Freeman et al. 1998; Tyrrell 2007b; Hoover et al. 2013). Some cultural practices, such as food sharing, which is important for families and social cohesiveness, are still practiced in all Nunavut communities. Other historical practices and traditional taboos may no longer be observed, such as sinking carcasses post-harvest to avoid attracting polar bears to harvest locations near communities. "Hunters do not sink the carcass. They just harvest it, and leave it on the shoreline. This is due in part why we're seeing more polar bears coming around... So you need to butcher it properly in order for the carcass to sink into the sea to leave it there" (Napayok 2018).

Research activities in Nunavut are beginning to be more attentive to the concerns of communities. The Kivalliq Wildlife Board has recently undertaken a community-based research project to sample whales harvested by Inuit youth to determine the health, trend and abundance of the population. Inuit are readily positioned to notice any changes in the environment. For example, Inuit have observed delays in the beluga migration. The cause remains uncertain, but the increased presence of killer whale (aarluk; Orcinus orca) in Hudson Bay waters observed by Inuit (Higdon and Ferguson 2009; Higdon et al. 2014) may be a potential factor (Westdal et al. 2016).

\section{Inuvialuit Settlement Region, Canada}

Inuvialuit and Canadian western Arctic Inuit annually hunt beluga whales (qilalugaq) from the eastern Beaufort 
Sea beluga population (Day 2002; Harwood et al. 2002), as did their ancestors, the Kupugmiut and Kigirktarumiut (McGhee 1974). Inuvialuit beluga hunters know the importance of respect for the beluga and continue cultural practices to take only what is needed and to share what is taken (Snow et al. 2016). Despite the influences of climate and societal changes, hunters remain adaptable and rely on traditional skills and knowledge as well as values of cooperation, harmony and readiness (Collings et al. 2018; Worden et al. 2020). Hunting typically occurs in summer from small aluminum boats using harpoon-first methods to reduce struck-and-lost incidents, following local by-laws developed by Hunters and Trappers Committees (Day 2002; Harwood \& Smith 2002; FJMC 2013). Because beluga aggregate in large numbers in the Mackenzie Estuary/Delta in summer (Norton \& Harwood 1986; Harwood et al. 1996), hunters operate from summer whaling camps occupied by families from Inuvik and Aklavik or directly from the coastal community of Tuktoyaktuk (Waugh et al. 2018; Worden et al. 2020).

Beyond the Mackenzie Delta area, a beluga harvest has taken place or been attempted by the community of Paulatuk in most years since 1989 (Harwood et al. 2002). Sporadic hunts have also occurred in Sachs Harbour and Ulukhaktok from 2010 to the present as the whales appear to be expanding their summer range (Collings et al. 2018; Loseto, Brewster et al. 2018; Loseto, Hoover et al. 2018). Concurrently, there has been a decline in the number of whales landed in Mackenzie Estuary hunts since the 1970s (FJMC 2013; Harwood et al. 2015), likely due to multiple social and environmental factors (Waugh et al. 2018; Scharffenberg et al. 2020; Harwood et al. 2020; Worden et al. 2020).

A co-management framework has been in place in the Inuvialuit Settlement Region since 1984. The federal government and the FJMC are responsible for fish and marine mammal management and related matters in the region. The federal government and the FJMC, in co-operation with Hunters and Trappers Committees, have developed conservation management strategies that include the creation of Canada's first two Arctic Marine Protected Areas: Tarium Niryutiat and Anuniaqvia Niqiqyuam Marine Protected Areas (also spelled Tagium Nayutiat and Anguniaqvia Niqigyuam in Inuvialuit orthography). Tarium Niryutiat focuses on beluga, beluga habitats and prey (DFO 2010), and Anuniaqvia Niqiqyuam includes the conservation of beluga and its habitat.

Nearly 40 years of eastern Beaufort Sea beluga cooperative research has resulted from these efforts in the Inuvialuit Settlement Region, generating one of the strongest Arctic beluga data sets (Loseto, Hoover et al. 2018; Harwood et al. 2020). The success of this programme is the result of a long-term, sustained and well-resourced collaborative effort between co-management boards, community members and the scientific community. Beluga research and monitoring has evolved over the past 40 years, responding to community questions, management needs and scientific investigations that have brought together a community of knowledge-holders working collaboratively to best study beluga. Beluga harvest monitoring has revealed a declining trend in size-at-age of male beluga in the Mackenzie Estuary from 1993 to 2007 (Harwood et al. 2015); dietary shifts and impacts on dive physiology (Choy et al. 2017; Choy et al. 2019; Choy et al. 2020); trends in contaminants (Loseto et al. 2015; Noel et al. 2018); microplastics in beluga (Moore et al. 2020); and diseases (Nielsen et al. 2018; Sharma et al. 2018). Community members are part of the planning and field crews, sometimes participate in laboratory analyses (typically youth) and often are part of the dissemination of results at meetings and conferences. Inclusion of Indigenous Knowledge has occurred and continues to occur through the co-development of the research and monitoring programmes (Armitage et al. 2011). The beluga harvest monitoring programme includes Indigenous Knowledge about beluga health and behaviour that are formally documented as long-term monitoring indicators (Ostertag et al. 2018).

There are additional and long-standing collaborations on research and management of eastern Beaufort Sea beluga, a shared stock, between the Inuvialuit Settlement Region and Alaska, building on several Iñupiat-Inuvialuit cooperative efforts (Kanayurak 2016). The InuvialuitIñupiat Beluga Whale Commission, which was created in 2000 from the Alaska-Inuvialuit Beluga Whale Committee (Adams et al. 1993), provides a way for hunters to interact with their peers from both regions and also to share scientific findings through a technical committee. The commission meets annually to discuss harvest numbers and current research, share unusual observations and other data and knowledge, and provide joint recommendations on the shared eastern Beaufort Sea beluga stock.

\section{Alaska, USA}

Beluga (qilalugaq, sisuaq, cetuaq) hunting practices in Alaska vary greatly among the more than 40 involved communities (Frost \& Suydam 2010) and at least five beluga stocks. In spring, beluga whales are hunted from the edge of the shorefast ice while in summer and fall they are taken in open water by net and rifle and by driving groups of beluga into shallow water. Apart from a prohibition on waste, there are no harvest limits at present (apart from a federally-imposed ban on any hunting of the endangered stock of beluga in Cook Inlet in southern Alaska [NOAA Fisheries 2021]), though in some local 
areas beluga are not as common as they once were. In all beluga-hunting communities, harvesting involves practices deemed respectful to the whales, including mental and physical preparation for the hunt, avoiding conflict among hunters, reducing the number of whales lost during the hunt and sharing the beluga within and beyond the community. While hunting practices have changed in some places with outboard motors, faster boats and better rifles, the values of sharing and respect are understood to be vital to the success of the harvest and to the cultural well-being of the communities (Huntington et al. 2017).

Collaborative research about beluga whales has a long history in Alaska, a practice that has increased since the founding of the co-management Alaska Beluga Whale Committee in 1988 (Adams et al. 1993). Hunters, scientists and managers together determine research priorities and carry out projects including aerial surveys (e.g., Lowry et al. 2008), satellite telemetry (Citta et al. 2017), genetic analyses (e.g., O'Corry-Crowe et al. 1997), health and contaminants research (e.g., Woshner et al. 2002; Thompson et al. 2014), Indigenous Knowledge documentation (e.g., Huntington et al. 1999; Huntington 2000) and assessment of management approaches (e.g., Fernandez-Gimenez et al. 2008). Hunters participating in research projects are increasingly recognized as co-authors and have also been certified as hunter-taggers by the US National Oceanic and Atmospheric Administration to catch and attach satellite transmitters to beluga, formally recognizing their abilities and role as researchers. The Alaska Beluga Whale Committee allocates funding for research projects, giving hunters a strong role in making such decisions, and provides a forum for addressing management issues.

\section{Chukotka, Russia}

Beluga whale (Chukchi: puwreq; Siberian Yupik: poogsyaq) hunting in Chukotka has a long and sustainable history diversifying the diet of local communities, although its contribution to the traditional economy is modest (Mymrin et al. 1999). Today, hunting obshchinas (communities) distributed in 14 villages along the Bering Strait region harvest no more than 20 beluga whales annually (Prochukotku.ru 2020a). From time to time, they are joined by a couple of settlements located on the Anadyr River, which take beluga entangled in salmon nets. Chukotka has an overall quota system for traditional hunting of marine mammals, which is distributed by the regional Fisheries Commission (Prochukotku.ru 2020b).

Beluga are hunted mainly in spring and late autumn, when the sea is covered by sea ice. Hunters (eveneellyet; Chukchi terms relevant to beluga hunting are provided here) prefer these seasons because beluga are very careful and almost impossible to approach by boat (yitw'et). Therefore, hunters usually shoot beluga from shore (an'k'asormyn) or the edge of shorefast ice (tukvan). Hunters first shoot (mil'gerytkurkyt) at the beluga and then either harpoon (tegryrkyt) them or use a wooden or metal hook $\left(a k^{\prime} y n\right)$ to pull them to the surface. Sometimes beluga are trapped in a small opening in the ice far from open water (iyogyrgyn), and local communities have a rare opportunity to provide themselves with tasty food. Hunters usually begin to butcher the animal (el'vyk) by cutting off the tail, then cut the skin and fat (itgil'gyn) into square strips, and then cut the meat (an' $\left.k^{\prime} a t o l^{\prime}\right)$ in the same way and remove the internal organs. The hunter who killed the beluga takes the head of the animal (l'evyt) and, after processing, returns it to the sea. The remaining parts of the beluga are distributed among hunters and also provided to neighbours (enaral'ety). In some villages, the belly (nank'ytol') and tail (peqalyan) of the beluga also belong to the hunter.

The Chukotka branch of Pacific Research Fisheries Center began a long-term study of beluga in Chukotka in the 1990s. Each year, expeditions to the Anadyr Estuary collected beluga biopsies and conducted visual animal counts and sometimes carried out satellite tagging and underwater sound studies (Litovka et al. 2013). Over time, scientists invited local hunters to cooperate. Indigenous Knowledge and hunting experience ensured the success of the expeditions to collect beluga biopsies and even attach satellite tags. Together, scientists and Native hunters were able to collect data on the current state of the local beluga whale population.

\section{Case study of knowledge co-production to support the conservation of an at-risk stock: Nunavik, Canada}

\section{Background and context}

There are four stocks of beluga in the Nunavik Marine Region, named for their summering grounds (Table 3, Fig. 2). We use 'stock' as the term is used in Nunavik, to define management units based on summering areas and supported by matrilineal genetic analysis, though there is likely interbreeding among at least some of the region's four stocks. Beluga tend to travel together with related individuals, particularly females, and to return to previously used areas, suggesting that migration may be learned through the social structure of more closely related individuals (Colbeck et al. 2013). The preservation of the beluga stocks from each of the summering aggregations is considered important to maintain the geographic range of beluga (Turgeon et al. 2012). 
Table 3. Estimated historical abundances, the most recent aerial survey abundance estimates and the updated 2020 COSEWIC stock status for the four different beluga stocks found in the Nunavik Marine Region. Estimates, particularly historical abundances and the recent estimate for Ungava Bay, are based on different methods.

\begin{tabular}{|c|c|c|c|}
\hline Beluga stock & Estimated historical abundance (year) & Abundance estimates (year) & COSEWIC stock status \\
\hline \multirow[t]{2}{*}{ EHB } & $>6600(1853)^{a}$ & $3800(2015)^{d, e}$ & Threatened (as of Nov. 2020) \\
\hline & $12500\left(\right.$ pre-1854) $^{b}$ & & \\
\hline WHB & $31100(1987)^{e}$ & $54500(2015)^{e}$ & Not at risk \\
\hline James Bay & unknown & $10600(2015)^{d, e}$ & Not at risk \\
\hline Ungava Bay & 1900 (late 1800s) $^{\text {b }}$ & $32(2011)^{c}$ & Endangered \\
\hline
\end{tabular}

${ }^{a}$ Reeves \& Mitchell (1987). ${ }^{\text {b }}$ DFO (2005). ${ }^{c}$ Doniol-Valcroze \& Hammill (2012); 95\% confidence interval = 0-94. ${ }^{d}$ Gosselin et al. $(2017) .{ }^{\text {e }}$ DFO 2018.

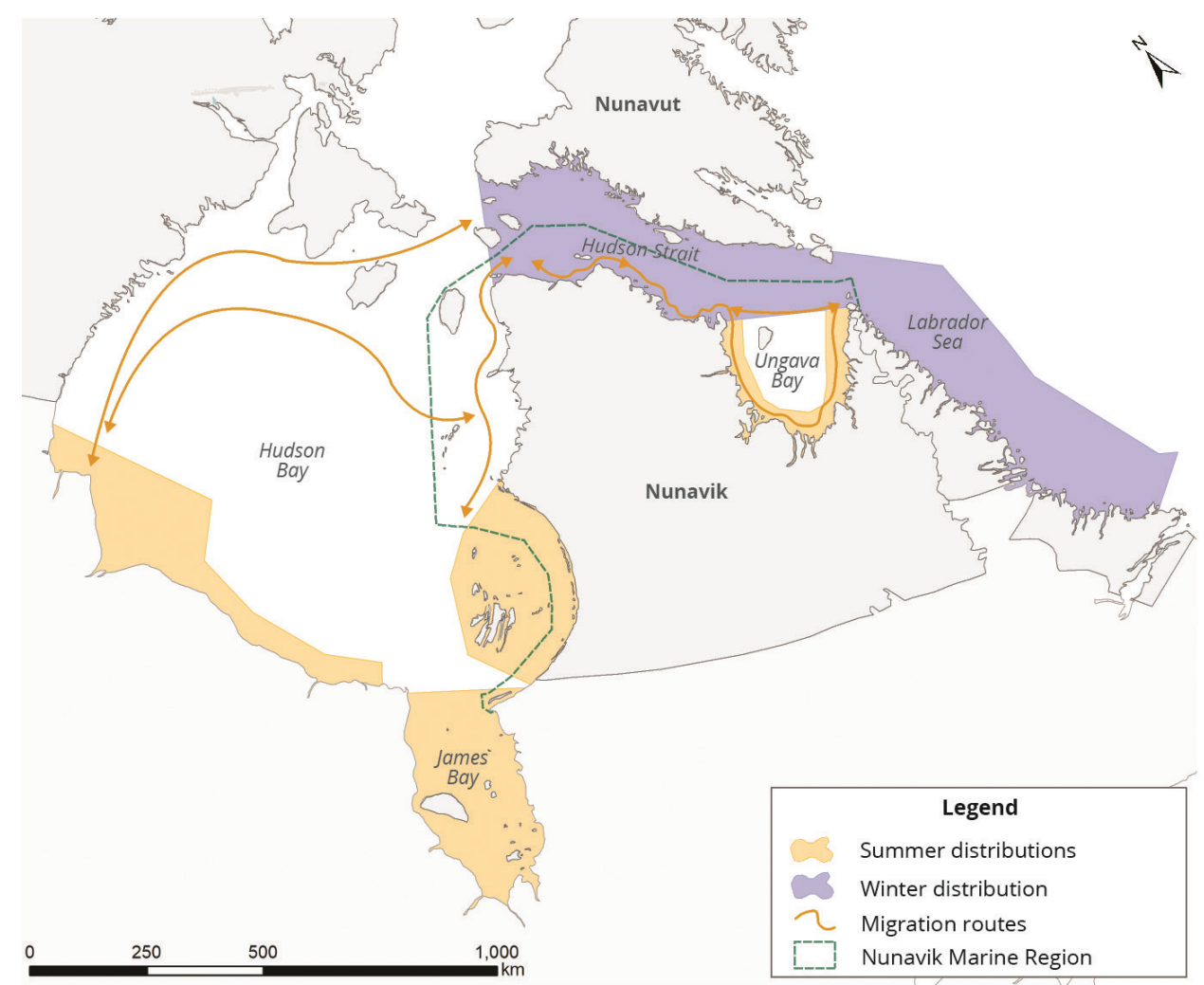

Fig. 2. Summering and wintering areas and approximate migratory routes for the four beluga stocks (WHB, James Bay, EHB and Ungava Bay beluga) which inhabit the Nunavik Marine Region for all or part of the year.

The EHB stock is of particular interest and challenge for managers (DFO 2020). Beluga in EHB were subject to heavy commercial harvesting from the mid-1800s until the early 1900s-an estimated minimum of 8294 whales were taken between 1854 and 1863-and the stock has not recovered (Reeves \& Mitchell 1987; DFO 2018). As a result, this stock, which was estimated to be approximately 3800 animals at the time of the last aerial survey in 2015 (Gosselin et al. 2017), is believed to be less than half of what it was historically (Hammill et al. 2017). After being considered endangered since 2004 (COSEWIC
2004), EHB beluga were reassessed by COSEWIC in late 2020 as threatened on the basis of the relative stability of the population, which has remained the same, or slightly increased, since 2001.

COSEWIC assessments consider factors such as declines in total number of mature animals, whether the reasons for the declines are known and still acting on the species, and whether there have been changes in distribution or range. Although Inuit harvesting is not considered to have played a part in the initial decline, it has been considered to limit stock recovery, after commercial 
hunting caused declines (DFO 2020). The EHB stock spends at least half the year spatially overlapping, and likely interbreeding, with the WHB stock in their shared wintering areas and during migration (Turgeon et al. 2012; Colbeck et al. 2013). Both stocks migrate through Hudson Strait in spring and fall. However, the WHB stock is estimated to number approximately 54500 animals (about 15 times the size of the EHB stock) and is not of conservation concern (DFO 2018).

While it is difficult for most hunters to discriminate between the stocks, expert hunters assert that they can distinguish animals from the different groups of beluga. However, no one has undertaken the work to determine whether there is a simple, reliable method to differentiate among stocks, aside from genetics, and this needs to be further explored.

\section{Nunavik beluga management}

Since the 1980s, different quota-based management approaches, including both seasonal and geographic limitations, have been applied. In the 1980s, management decisions were taken and implemented by the federally responsible Minister. Since NILCA came into force in 2008, decision-making has shifted to a formal co-management process. Through the NILCA, the NMRWB was established and is tasked with being the main instrument of wildlife management in the Nunavik Marine Region, including the establishment and modification of the TAT for beluga. The decisions of the NMRWB are delivered for approval to the minister of the government department that has responsibility for the species in question, which is DFO in the case of beluga whales, as government has the ultimate responsibility for wildlife management. Regulation in the Nunavik Marine Region is further complicated by overlapping rights between Nunavik Inuit and the Cree of Eeyou Istchee. Wildlife management in the south-eastern part of Hudson Bay is shared with the Eeyou Marine Region Wildlife Board.

Prior to NILCA, conservation guided decision-making. Under NILCA, a constitutionally protected document, Inuit rights can only be infringed upon under limited, defined circumstances. Therefore, the NMRWB is required both to uphold the principles of conservation, including the restoration and revitalization of depleted population of wildlife, and to protect the harvesting rights of Nunavik Inuit. Given the conservation concerns related to the EHB beluga, a quota-based system has remained in place until the present.

Under NILCA wildlife management provisions, the entirety of the beluga TAT is presumed to be needed by Nunavik Inuit, and non-Indigenous people are prohibited from harvesting beluga. Allocation of the TAT among
Nunavik communities is determined by the regional hunting organization. The community allocation can then be further allocated by the local community hunting organization if they so choose, but in practice it is usually an open hunt until the quota is reached. Since 2014, the TAT has been set in multi-year (e.g., 3-5 year) blocks to account for variations in environmental conditions, beluga abundance and community needs, providing a greater degree of flexibility. Importantly, the TAT has been solely for EHB beluga since 2014. Communities have Uumajuit Wardens, who monitor and report the harvest, but have no enforcement power, while DFO Fisheries Officers from outside of the region are responsible for enforcing variation orders, acts and regulations (Gombay 2019).

Given the challenges of distinguishing between stocks, tracking harvest levels of EHB beluga is based upon assumed proportions of EHB beluga in the total harvest, with differing proportions depending on the season and hunting area. This proportion is determined using genetic information gathered from previous Inuit harvests. Despite the changes in the management system, and the shift to a co-management framework, challenges remain in a system that strives to balance conservation with minimizing limits on harvesting rights. Indeed, the TAT for EHB beluga continues to be reached in some years, resulting in the closure of the entire hunt before or during the fall migration, a hunt of great importance for Nunavimmiut. Hunters then watch tens of thousands of beluga-mostly from stocks that are not the subject of conservation concern-migrate past their communities and are unable to exercise their harvesting rights.

Re-allocation of hunting effort to ensure hunting is allowed during the seasons when EHB beluga are less likely to be caught could rectify this situation but must be balanced with respecting the harvesting rights of Inuit and the traditional hunting activities of communities more likely to catch EHB beluga. This management model, however, continues to contradict the spirit and intent of NILCA and minimal infringement of harvesting rights, since harvest of the large and healthy stock of WHB beluga has also been limited in the course of efforts to conserve EHB beluga. The NMRWB is left with the challenge of determining how to manage harvesting of two visually cryptic stocks of beluga with highly coincidental geographic distributions, but vastly different conservation status.

\section{Bringing Inuit knowledge of migratory timing and genetics together in the Hudson Strait Pilot Project}

The Hudson Strait Pilot Project was implemented in 2017 as a way of using co-produced knowledge to best balance 
EHB conservation and harvesting rights. The project uses Inuit knowledge of migration timing to avoid harvesting the EHB stock as much as possible, while focusing harvesting on the healthy WHB stock. Genetic sampling of the harvest is then used to assess the level of success in avoiding the EHB stock. Neither Inuit knowledge nor the genetic sampling would be sufficient by itself, making a knowledge co-production approach necessary.

Past genetic sampling has determined the proportions of EHB and WHB beluga at different times of year. This information serves as the basis to set the TAT for EHB beluga in the Nunavik Marine Region. For example, in Hudson Strait in the spring, only $10 \%$ of beluga are estimated to be EHB, meaning that the harvest of one beluga removes 0.1 beluga from the overall EHB TAT for the Nunavik Marine Region. However, in the EHB arc, where $100 \%$ of beluga are assumed to be EHB, one beluga harvested removes one beluga from the TAT. This allows flexibility in the quota system but causes problems if areas and seasons are not determined at a scale that captures a true estimate of stock mixing at a given time. For example, the entirety of fall (1 September - 31 January) is considered one season in Hudson Strait. However, Inuit knowledge from experienced hunters indicates that a smaller migration occurs through Hudson Strait a few weeks before a larger migration. This smaller group is understood to be the EHB beluga migrating in advance of the WHB beluga.

In previous management systems, quotas were often annual, which created an inherent challenge in the management system where hunters rushed to harvest early in the fall, before the quota was reached and the hunt was closed. Within the current management system there are multi-year TATs; however, allocations by the regional hunting organization are still made annually, and usually broken down into a spring and fall harvest, and hunters remain concerned that if they wait to harvest they will miss out on their opportunity to harvest what they need. This rush to hunt in the fall means that hunters are more likely to harvest from the earlier groups of whales, thought to be EHB beluga. This may also be part of the reason why the proportion of EHB beluga in the fall harvest $(25 \%)$ is higher than in spring $(10 \% \mathrm{EHB})$. While genetic testing can help validate this knowledge, there are few genetic harvest samples from the late fall because harvests have primarily occurred in the early fall (due to the rush described above) and it is not yet possible to achieve the temporal resolution required. This indicates a situation in which Nunavik Inuit hunting may be limited more than necessary and the harvest of EHB beluga could be better reduced.

During the management decision-making process leading to the 2017-19 harvest seasons, hunters shared this Inuit knowledge with the NMRWB regarding migration patterns and viewed it as an important area of potential improvement. In response, the NMRWB developed the Hudson Strait Pilot Project, encouraging harvesters to harvest later in the fall, in October and November, from the larger migrating group and to sample their harvest to determine the animals' stock. To counter the pressure to hunt earlier under a TAT system, the NMRWB decided that successful avoidance of EHB beluga, verified with genetic samples, would lead to any unused harvest being carried over to the TAT in the following year.

\section{Hudson Strait Pilot Project outcomes}

The project was successful in 2017 and 2018; however, in 2019, which was the final year of three-year plan, the hunt was closed before the commencement of the pilot project. Between 2017 and 2018, 44 beluga were sampled as part of the pilot project. Based upon the assumed proportions used for management of $25 \% \mathrm{EHB}$, it was expected that 11 of those 44 whales would be EHB beluga. Genetic analysis showed that only seven of the 44 beluga harvested were EHB whales (Table 4) resulting in a return of four EHB to the TAT. Under the proportional TAT system, the return of four EHB to the TAT is significant, allowing from four to 40 extra beluga to be harvested, depending on the area and season, which is why fractions were included.

Rather than considering scientific information and Inuit knowledge information as two separate pieces of evidence for decision-making, this project integrated the two into a single line of evidence, providing a level of information and knowledge more valuable to all parties than would be possible otherwise. The project has also increased overall hunter support for the harvest monitoring programme and harvest samples substantially increased during the pilot project. The success of the project allowed managers to move forward with a better understanding of the biological system, and therefore with better tools to address conservation concerns while minimally limiting harvesting rights. While this question

Table 4. Pilot project sampling results from 2017 and 2018 with the expected EHB beluga take determined by multiplying the number sampled by $25 \%$, the expected percent of EHB in the stock mixture. Note that total samples shown are only those taken during the pilot project time frame. The small sample size requires cautious interpretation.

\begin{tabular}{lccc}
\hline & 2017 & 2018 & Total \\
\hline Sampled & 31 & 13 & 44 \\
Expected EHB (removed from TAT) & 7.75 & 3.25 & 11 \\
Actual EHB & 6 & 1 & 7 \\
Difference (returned to TAT) & 1.75 & 2.25 & 4 \\
\hline
\end{tabular}


is specific to beluga in the Nunavik Marine Region, aspects of this issue and solution are relevant to managers working under modern land claims and others who must consider other priorities and needs along with sustaining wildlife populations.

\section{Discussion}

Indigenous stewardship emphasizes cooperation among people through practices such as sharing and the relationship that is understood to exist between people and animals and that is shown, for example, through respect for what one has harvested. Co-management and collaborative research strive for cooperation and harmony through listening, communication, building and maintaining relationships, and working together to identify and achieve common goals and create shared understandings. A synthesis of the regional descriptions, including traditional values, stewardship practices, management authority and collaborative research activities (Table 2) shows many common themes in values and stewardship, as well as the breadth of collaborative research across the entire region. The Nunavik case study highlights the strength of a co-production model for bringing knowledge together to support both harvesting and conservation. This example is relevant not only to other beluga populations but is more broadly applicable, particularly to the stewardship of other large migratory and harvested species, such as green sea turtles (Chelonia mydas) and dugongs (Dugong dugon), about which the values and discourse between managers and harvesters also differ (Nursey-Bray et al. 2010).

The challenge today is to build on what has been accomplished already, in the context of continuing environmental and social change. Co-management and other collaborative efforts have led the way to develop management plans that ensure hunting is sustainable, but often have little influence over climate change, shipping, industrial development, pollution and other threats to the health and abundance of beluga. Some beluga stocks are abundant and healthy, whereas others are small and declining. Stocks used by different communities within a region, among regions or internationally require an additional level of management cooperation, as can be seen in regional organizations as well as international ones such as the Inuvialuit-Iñupiat Beluga Commission, in the Beaufort Sea, and the Joint Commission on Narwhal and Beluga, in Baffin Bay. Collaborative research has greatly increased our understanding of beluga whales and their ecosystems, but rapid environmental changes may alter beluga behaviour and distribution, rendering much of current understanding at risk of being dated and eventually obsolete. Greater recognition of the importance of Indigenous values, knowledge and stewardship-not least among Indigenous communities themselves-has helped spur Indigenous-led efforts to conserve beluga and their abundance, but rapid social change may interfere with passing these traditions down to younger generations (Pearce et al. 2011). The hard-won gains of cooperation are still vulnerable to being lost or weakened without continued investment of time and effort, the more so as knowledge-both Indigenous and scientificneeds to be kept up to date.

The application of outside wildlife management measures to Indigenous hunting practices in the Arctic has often created tensions or conflicts and has sometimes countered conservation efforts (Huntington 1992; Meltofte 2013), as exemplified by the Nunavik case presented here (Tyrell 2007a,b, 2008). The recognition of the depth of Indigenous knowledge, the growth in collaborative research and the development of a forum through co-management systems have all helped transform interactions among hunters, researchers and managers toward a shared commitment to conserving abundant wildlife and sustaining Indigenous ways of life (Armitage et al. 2011 ; Huntington et al. 2011; Breton-Honeyman, Furgal et al. 2016; Snook et al. 2018). These steps are not panaceas, requiring hard and honest conversations, and each has created controversy and opposition at times (Fernandez-Gimenez et al. 2006), but such efforts are an important contribution to the well-being of the environment and its inhabitants. As participants in the Mystic workshop found, sharing ideas and experiences across regions, especially among Indigenous communities, can help reinforce the importance of stewardship and collaboration and inspire further efforts as one region finds new ideas from another. In Canada, it is hoped that the creation of the new DFO Arctic Region, which will include all of Inuit Nunangat, will increase effectiveness and further these collaborative efforts among regions (DFO 2021).

Efforts within beluga hunting communities to sustain traditional Indigenous stewardship are necessary to pass on the values and knowledge that have been gained over countless generations and adapted to the needs of each time (Worden et al. 2020). Efforts are also necessary among hunters, researchers and managers so that our understanding keeps pace with change, that we are able together to address the range of challenges facing beluga and hunting communities, and that we pass on not only knowledge but also the values that support such collaboration. Retaining the status quo is insufficient. Internationally, Indigenous peoples are calling for a transformative shift in power and changes in how research is prioritized, conducted and implemented across the Arctic with self-determination at the foundation (Obed 2016; Inuit Circumpolar Council 2018; Inuit Tapiriit Kanatami 2018). 
The increased attention to Indigenous Knowledge and Indigenous participation in research and management is a major cultural shift in recent decades but is still in the early stages. More can and should be done (Pearce et al. 2009; Loseto et al. 2020). For authentic, meaningful collaboration and change, hunters and those impacted by the research and decisions need to be involved in all stages of a project or management system (Huntington 2021). At present, however, much hunter inclusion in research remains on a voluntary, contractual or shortterm basis, rather than as a means of livelihood as is the case for professional scientists and managers. This split creates a power imbalance and a pervasive perception that formal scientific research has greater value and status. Studies involving Indigenous Knowledge are more common, but still outnumbered by biological research papers, and studies are rarely led by Indigenous scholars (Breton-Honeyman, Furgal et al. 2016; Alexander et al. 2019). Changing these ways will require expanded research funding, the re-allocation of existing funding, or both (Inuit Tapiriit Kanatami 2018).

Beluga-qilalugaq, qinalugaq, sisuaq, cetuaq, puwreq, poogsyaq-are found throughout the Arctic and, for reasons of geography, history and culture, are hunted across half the Arctic. Much remains to be learned from one another, from understanding how a changing environment affects beluga to sharing successes in research and collaboration and emphasizing the importance and consistency of Indigenous values and stewardship across a vast area, as has been started with the Inuvialuit-Iñupiat collaboration in the Beaufort Sea and the InuitGreenlandic cooperation in Baffin Bay. In addition, more research is needed to compare management systems and experiences to determine how the results of collaborative research are applied locally, regionally and internationally. The future of beluga whales and beluga hunting communities depends on continued cooperation and communication among all who share a vision of abundance in the Arctic.

\section{In memoriam}

During the review of this paper, our friend, colleague and co-author, Alfred Jakobsen, passed away. We honour his life-long passion for his home of Greenland, for all Inuit and for the Arctic, and for the

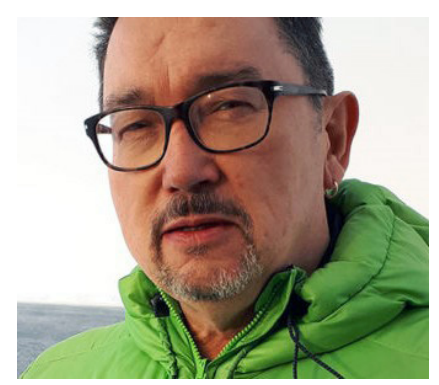
humour and insight with which he shared that passion. (Photo courtesy of Oceans North.)

\section{Acknowledgements}

We gratefully acknowledge Kristin Laidre, University of Washington; Fernando Ugarte, Greenland Institute of Natural Resources; Mike Hammill and Jeremiah Young, DFO; Robert Moshenko, Jean-Pierre Savard and Qajaq Robinson, NMRWB; Kathy Frost, Alaska Beluga Whale Committee; Davonna Kasook, Inuvialuit Game Council; Lois Harwood, FJMC, for their constructive reviews of earlier drafts of this manuscript. We further thank Marjo Vierros and an anonymous reviewer for their constructive comments on the manuscript.

\section{Disclosure statement}

The authors report no conflict of interest.

\section{Funding}

No specific funding was used in the writing of this paper, beyond institutional support for some co-authors' time.

\section{References}

Adams M., Frost, K.J. \& Harwood L. 1993. Alaska and Inuvialuit Beluga Whale Committee (AIBWC)-an initiative in "at home management." Arctic 46, 134-137, doi: $10.14430 /$ arcticl334.

Alayco S., Bergeron M. \& Michaud M.D. 2007. Inuit elders and their Traditional Knowledge: beluga hunting and sustainable practices. Westmount, QC: Avataq Cultural Institute / Ottawa: Fisheries and Oceans Canada.

Alexander S.M., Provencher J.F., Henri D.A., Taylor J.J., Lloren J.I., Nanayakkara L., Johnson J.T. \& Cooke S.J.. 2019. Bridging Indigenous and science-based knowledge in coastal and marine research, monitoring, and management in Canada. Environmental Evidence 8, article no. 36, doi: 10.1186/s13750-019-0181-3.

Armitage D., Berkes F., Dale A., Kocho-Schellenberg E. \& Patton E. 2011. Co-management and the co-production of knowledge: learning to adapt in Canada's Arctic. Global Environmental Change 21, 995-1004, doi: 10.1016/j. gloenvcha.2011.04.006.

Bailleul F., Lesage V., Power M., Doidge D.W. \& Hammill M.O. 2012a. Differences in diving and movement patterns of two groups of beluga whales in a changing Arctic environment reveal discrete populations. Endangered Species Research 17, 27-41, doi: 10.3354/esr00420.

Bailleul, F., Lesage V., Power M., Doidge D.W \& Hammill M.O. 2012b. Migration phenology of beluga whales in a changing Arctic. Climate Research 53, 169-178 doi: 10.3354/ cr01104.

Blanchet C. \& Rochette L. 2008. Nutrition and food consumption among the Inuit of Nunavik. Nunavik Inuit Health Survey 2004, Qanuippitaa? How are we? Quebec: Institut National 
de Santé Publique du Québec and Nunavik Regional Board of Health and Social Services.

Breton-Honeyman K., Hammill M.O., Furgal C.M. \& Hickie B. 2016. Inuit knowledge of beluga whale (Delphinapterus leucas ) foraging ecology in Nunavik (Arctic Quebec), Canada. Canadian Journal of Zoology 94, 713-726, doi: 10.1139/ cjz-2015-0259.

Breton-Honeyman K., Furgal C.M. \& Hammill M.O. 2016. Systematic review and critique of the contributions of Traditional Ecological Knowledge of beluga whales in the marine mammal literature. Arctic 69, 37-46, doi: 10.14430/ $\operatorname{arctic} 4543$.

Brice-Bennett C. (ed.) 1977. Our footprints are everywhere: Inuit land use and occupancy in Labrador. Nain, NL: Labrador Inuit Association.

Brice-Bennett C. 1978. An overview of the occurrence of cetaceans along the northern Labrador coast. Report for Offshore Labrador Biological Studies Program. St. John's, NL: Northern Environmental Protection Branch, Northern Affairs Program.

Choy E.S., Campbell K.L., Berenbrink M., Roth J. \& Loseto L.L. 2019. Body condition impacts blood and muscle oxygen storage capacity of free-living beluga whales (Delphinapterus leucas). Journal of Experimental Biology 222, jeb191916, doi: 10.1242/jeb.191916.

Choy E.S., Giraldo C., Rosenberg B. Roth J.D., Stasko A., Majewski A., Swanson H., Power M., Reist J.D. \& Loseto L.L. 2020. Variation in the diet of beluga whales in response to changes in prey availability: insights on changes in the Beaufort Sea ecosystem. Marine Ecology Progress Series 647, 195-210, doi: 10.3354/meps13413.

Choy E.S., Rosenberg B., Roth J.D. \& Loseto L.L. 2017. Interannual variations in environmental factors affect prey and body condition of eastern Beaufort Sea beluga whales (Delphinapterus leucas). Marine Ecology Progress Series 579, 201-212, doi: 10.3354/meps12256.

Citta J.J., Richard P., Lowry L.F., O'Corry-Crowe G., Marcoux M., Suydam R., Quakenbush L.T., Hobbs R.C., Litovka D.I., Frost K.J., Gray T., Orr J., Tinker B., Aderman H. \& Druckenmiller M.L. 2017. Satellite telemetry reveals population specific winter ranges of beluga whales in the Bering Sea. Marine Mammal Science 33, 236-250, doi: $10.1111 / \mathrm{mms} .12357$.

Colbeck G.J., Duchesne P., Postma L.D., Lesage V., Hammill M.O. \& Turgeon J. 2013. Groups of related belugas (Delphinapterus leucas) travel together during their seasonal migrations in and around Hudson Bay. Proceedings of the Royal Society of Biological Sciences 280, article no. 20122552, doi: 10.1098/rspb.2012.2552.

Collings P., Pearce T. \& Kann J. 2018. “We don't know anything about whales": ecological knowledge and ways of knowing in Ulukhaktok, Northwest Territories, Canada. Arctic Science 241, 223-241, doi: 10.1139/as-2017-0030.

COSEWIC 2004. COSEWIC assessment and update status report on the beluga whale Delphinapterus leucas in Canada. Ottawa: Committee on the Status of Endangered Wildlife in Canada.

Day B. 2002. Renewable resources of the Beaufort Sea for our children: perspectives from an Inuvialuit elder. Arctic 55, Supplement 1, 1-3, doi: 10.14430/arctic730.
DFO 2005. Recovery potential assessment of Cumberland Sound, Ungava Bay, eastern Hudson Bay and St. Lawrence beluga populations (Delphinapterus leucas). Canadian Science Advisory Secretariat Science Advisory Report 2005/036. Ottawa: Fisheries and Oceans Canada.

DFO 2010. Monitoring indicators for the Tarium Niryutait Marine Protected Area (TNMPA). Canadian Science Advisory Secretariat Science Advisory Report 2010/059. Ottawa: Fisheries and Oceans Canada.

DFO 2013. Identification of additional ecologically and biologically significant areas (EBSAs) within the Newfoundland and Labrador Shelves Bioregion. Canadian Science Advisory Secretariat Science Advisory Report 2013/048. Ottawa: Fisheries and Oceans Canada.

DFO 2018. Harvest advice for eastern and western Hudson Bay beluga (Delphinapterus leucas). Canadian Science Advisory Secretariat Science Advisory Report 2018/008. Ottawa: Fisheries and Oceans Canada.

DFO 2020. 2020 harvest advice for eastern Hudson Bay beluga (Delphinapterus leucas). Canadian Science Advisory Secretariat Science Advisory Report 2020/031. Ottawa: Fisheries and Oceans Canada.

DFO 2021. Fisheries and Oceans Canada and Canadian Coast Guard confirm new regions' boundaries to improve services to the Arctic. Accessed on the internet at https:// www.canada.ca/en/fisheries-oceans/news/2021/03/ fisheries-and-oceans-canada-and-canadian-coast-guardconfirm-new-regions-boundaries-to-improve-services-tothe-arctic.html on 19 October 2021.

Doidge W., Adams W. \& Burgy C. 2002. Traditional Ecological Knowledge of beluga whales in Nunavik: interviews from Puvirnituq, Umiujaq and Kuujjuaraapik. Report 12-419 of the Nunavik Research Centre submitted to Environment Canada's Habitat Stewardship Program for Species at Risk. Kuujjuaq, QC: Makivik Corporation.

Doniol-Valcroze T. \& Hammill M.O. 2012. Information on abundance and harvest of Ungava Bay beluga. Canadian Science Advisory Secretariat Research Document 2011/126. Ottawa: Fisheries and Oceans Canada.

Fernandez-Gimenez M.E., Huntington H.P. \& Frost K.J. 2006. Integration or co-optation? Traditional Knowledge and science in the Alaska Beluga Whale Committee. Environmental Conservation 33, 306-315, doi: 10.1017/ S0376892906003420.

Fernandez-Gimenez, M.E., Hays J.U. Jr., Huntington H.P., Andrew R. \& Goodwin W. 2008. Ambivalence toward formalizing customary resource management norms among Alaska Native beluga whale hunters and Tohono O'odham livestock owners. Human Organization 67, 137-150, doi: 10.17730/humo.67.2.008083027273n05q.

FJMC 2013. Beaufort Sea Beluga Management Plan. 4th amended printing. Inuvik, NT: Fisheries Joint Management Committee.

Freeman M.M.R. 1993. The International Whaling Commission, small type whaling, and coming to terms with subsistence. Human Organization 52, 243-251.

Freeman M.M.R., Bogoslovskaya L., Caulfield R.A., Egede I., Krupnik I.I. \& Stevenson M.G. (eds.) 1998. Inuit, whaling, and sustainability. Walnut Creek, CA: AltaMira Press. 
Frost K.J. \& Suydam R.S. 2010. Subsistence harvest of beluga or white whales (Delphinapterus leucas) in northern and western Alaska, 1987-2006. Journal of Cetacean Research Management 11, 293-299.

Gombay N. 2019. Wildlife management in Nunavik: structures, operations, and perceptions following the James Bay and Northern Quebec Agreement. Arctic 72, 181-196, doi: 10.14430/arctic68287.

Gosselin J.-F., Hammill M.O. \& Mosnier A. 2017. Indices of abundance for beluga (Delphinapterus leucas) in James Bay and eastern Hudson Bay in summer 2015. Canadian Science Advisory Secretariat Research Document 2017/067. Ottawa: Fisheries and Oceans Canada.

Hammill M.O., Lesage V., Gosselin J.-F., Bourdages H., De March B.G.E. \& Kingsley M.C.S. 2004. Evidence for a decline in northern Quebec (Nunavik) belugas. Arctic 57, 183-195.

Hammill M.O., Stenson G.B. \& Doniol-Valcroze T. 2017. A management framework for Nunavik beluga. Canadian Science Advisory Secretariat Research Document 2017/060. Ottawa: Fisheries and Oceans Canada.

Harwood L.A., Innes S., Norton P. \& Kingsley M.C.S. 1996. Distribution and abundance of beluga whales in the Mackenzie Estuary, southeast Beaufort Sea, and west Amundsen Gulf during late July 1992. Canadian Journal of Fisheries and Aquatic Sciences 53, 2262-2273, doi: 10.1139/ f96-180.

Harwood L.A., Kingsley M.C.S. \& Pokiak F. 2015. Monitoring beluga harvests in the Mackenzie Delta and near Paulatuk, NT, Canada: harvest efficiency and trend, size and sex of landed whales, and reproduction, 1970-2009. Canadian Manuscript Report of Fisheries and Aquatic Sciences 3059. Winnipeg: Fisheries and Oceans Canada.

Harwood L.A., Norton P., Day B. \& Hall P.A. 2002. The harvest of beluga whales in Canada's western Arctic: hunter-based monitoring of the size and composition of the catch. Arctic 55, 10-20, doi: 10.14430/arctic687.

Harwood L.A. \& Smith T.G. 2002. Whales of the Inuvialuit Settlement Region in Canada's western Arctic: an overview and outlook. Arctic 55, 77-93, doi: 10.14430/arctic736.

Harwood L.A., Zhu X., Angasuk L., Emaghok L., Ferguson S., Gruben C., Gruben P., Hall P., Illasiak J., Illasiak J., Lennie J., Lea E.V., Loseto L.L., Norton P., Pokiak C., Pokiak F., Rogers H., Snow K. \& Storr W. 2020. Research, monitoring and hunter knowledge in support of the 2017 assessment of the eastern Beaufort Sea beluga stock. Canadian Science Advisory Secretariat Research Document 2020/075. Ottawa: Fisheries and Oceans Canada.

Heide-Jørgensen M.P., Hansen R.G., Fossette S., Nielsen N.H., Borchers D.L., Stern H. \& Witting L. 2017. Rebuilding beluga stocks in west Greenland. Animal Conservation 20, 282-293, doi: 10.1111/acv.12315.

Heide-Jørgensen M.P., Laidre K., Borchers D., Marques T., Stern H. \& Simon M. 2010. The effect of sea-ice loss on beluga whales (Delphinapterus leucas) in west Greenland. Polar Research 29, 198-208, doi: 10.3402/polar.v29i2.6061.

Higdon J.W. \& Ferguson S.H. 2009. Loss of Arctic sea ice causing punctuated change in sightings of killer whales
(Orcinus orca) over the past century. Ecological Applications 19, 1365-1375, doi: 10.1890/07-1941.1.

Higdon J.W., Westdal K.H. \& Ferguson S.H. 2014. Distribution and abundance of killer whales (Orcinus orca) in Nunavut, Canada-an Inuit knowledge survey. Journal of the Marine Biological Association of the UK 94, 1293-1304, doi: 10.1017/ S0025315413000921.

Hobbs R.C., Reeves R.R., Prewitt J.S., Desportes G., BretonHoneyman K., Christensen T., Citta J.J., Ferguson S.H., Frost K.J., Garde E., Gavrilo M., Ghazal M., Glazov D.M., Gosselin J.-F., Hammill M., Hansen R.G., Harwood L., Heide-Jørgensen M.P., Inglangasuk G., Kovacs K.M., Krasnova V.V., Kuznetsova D.M., Lee D.S., Lesage V., Litovka D.I., Lorenzen E.D., Lowry L.F., Lydersen C., Matthews C.J.D., Meschersky I.G., Mosnier A., O'CorryCrowe G., Postma L., Quakenbush L.T., Shpak O.V., Skovrind M., Suydam R.S. \& Watt C.A. 2019. Global review of the conservation status of monodontid stocks. Marine Fisheries Review 81, 1-53, doi: 10.7755/ MFR.81.3-4.1.

Hoover C., Bailey M., Higdon J., Ferguson S.H. \& Sumaila R. 2013. Estimating the economic value of narwhal and beluga hunts in Hudson Bay, Nunavut. Arctic 66, 1-16, doi: 10.14430/arctic4261.

Huntington H.P. 1992. Wildlife management and subsistence hunting in Alaska. London: Belhaven Press.

Huntington H.P. 2000. Traditional Knowledge of the ecology of belugas, Delphinapterus leucas, in Cook Inlet, Alaska. Marine Fisheries Review 62, 134-140.

Huntington H.P. 2021. Engaging with Indigenous Environmental Knowledge in the North American Arctic: moving from documentation to decisions in environmental governance. In T.F. Thornton \& S.A. Bhagwat (eds.): The Routledge handbook of Indigenous Environmental Knowledge. Pp. 146-152. London: Routledge.

Huntington H.P. \& the Communities of Buckland, Elim, Koyuk, Point Lay and Shaktoolik. 1999. Traditional Knowledge of the ecology of beluga whales (Delphinapterus leucas) in the eastern Chukchi and northern Bering seas, Alaska. Arctic 52, 49-61.

Huntington H.P., Gearheard S., Mahoney A.R. \& Salomon A.K. 2011. Integrating traditional and scientific knowledge through collaborative natural science field research: identifying elements for success. Arctic 64, 437-445, doi: 10.14430/arctic4143.

Huntington H.P., Quakenbush L.T. \& Nelson M. 2017. Evaluating the effects of climate change on Indigenous marine mammal hunting in northern and western Alaska using Traditional Knowledge. Frontiers in Marine Science 4, article no. 319, doi: 10.3389/fmars.2017.00319.

Inuit Circumpolar Council 2018. Inuit Circumpolar Council Wildlife Management Summit report. Ottawa: Inuit Circumpolar Council.

Inuit Tapiriit Kanatami 2018. National Inuit strategy on research. Ottawa: Inuit Tapiriit Kanatami.

Kanayurak N.L. 2016. A case study of polar bear co-management in Alaska. Master's thesis, University of Washington, Seattle, WA. 
Kenny T. \& Chan H.M. 2017. Estimating wildlife harvest based on reported consumption by Inuit in the Canadian Arctic. Arctic 70, 1-12, doi: 10.14430/arctic4625.

Kilabuk P. 1998. A study of Inuit knowledge of the southeast Baffin beluga. Iqaluit, NU: Nunavut Wildlife Management Board.

Lee D., Doidge W., Burgy C. \& Adams W. 2002. Traditional Ecological Knowledge in relation to the management of beluga whales in Nunavik. Phase I. Interviews at Kangirsuk, Salluit and Inukjuak. Kuujjuaq, QC: Makivik Corporation.

Lemire M., Kwan M., Laouan-Sidi A.E, Muckle G., Pirkle C., Ayotte P. \& Dewailly E. 2015. Local country food sources of methylmercury, selenium and omega-3 fatty acids in Nunavik, northern Quebec. Science of the Total Environment 509/510, 248-259, doi: 10.1016/j.scitotenv.2014.07.102.

Lewis A.E., Hammill M.O., Power M., Doidge D.W. \& Lesage V. 2009. Movement and aggregation of eastern Hudson Bay beluga whales (Delphinapterus leucas): a comparison of patterns found through satellite telemetry and Nunavik Traditional Ecological Knowledge. Arctic 62, 13-24, doi: 10.14430/ARCTIC 109.

Litovka D.I., Andronov P.Y. \& Batanov R.L. 2013. Seasonal distribution of beluga whales Delphinapterus leucas depending on prey concentrations in coastal waters of north-western Bering Sea. The Researches of the Aquatic Biological Resources of Kamchatka and of the Northwest Part of the Pacific Ocean 28. Petropavlovsk-Kamchatsky, Russia: Kamchatka Research Institute of Fisheries and Oceanography. (In Russian with English title and abstract.)

Little M., Achouba A., Dumas P., Ouellet N., Ayotte P. \& Lemire M. 2019. Determinants of selenoneine concentration in red blood cells of Inuit from Nunavik (northern Québec, Canada). Environment International 127, 243-252, doi: 10.1016/j.envint.2018.11.077.

Loseto L.L., Breton-Honeyman K., Etiendem D.N., Johnson N., Pearce T., Allen J., Amos A., Arqviq J. Baak J., Belanger E., Bourdages M., Brammer J., Fawcett D., Gerin-Lajoie J., Gilbert G., Hansen-Craik K., Loring E., Perrin A. \& Slavitch M. 2020. Indigenous participation in peer review publications and the editorial process: reflections from a workshop. Arctic Science 6, 352-360, doi: 10.1139/as-2020-0023.

Loseto L.L. Brewster J.D., Ostertag S., Snow K., MacPhee S.A., McNicholl D.G., Choy E.S., Giraldo C. \& Hornby C. 2018. Diet and feeding observations from an unusual beluga harvest in Ulukhaktok Northwest Territories, Canada. Arctic Science 4, 421-431, doi: 10.1139/as-2017-0046.

Loseto L.L., Hoover C.H., Ostertag S.K., Whalen D., Pearce T., Paulic J., Iacozza J. \& MacPhee S. 2018. Beluga whales (Delphinapterus leucas), environmental change and marine protected areas in the western Canadian Arctic. Estuarine and Coastal Shelf Systems 212, 128-137, doi: 10.1016/j. ecss.2018.05.026.

Loseto L.L., Stern G.A. \& Macdonald R.M. 2015. Distant drivers or local signals: where do mercury trends in western Arctic belugas originate? Science of the Total Environment 509/510, 226-236, doi: 10.1016/j.scitotenv.2014.10.110.

Lowry L.F., Frost K.J., Zerbini A., DeMaster D. \& Reeves R.R. 2008. Trend in aerial counts of beluga or white whales (Delphinapterus leucas) in Bristol Bay, Alaska, 1993-2005. Journal of Cetacean Research Management 10, 201-207.
Lucier C.V. \& VanStone J.W. 1995. Traditional beluga drives of the Iñupiat of Kotzebue Sound, Alaska. Fieldiana. Anthropology new series 25. Chicago: Field Museum of Natural History.

Matthews C.J.D., Watt C.A., Asselin N.C., Dunn J.B., Young B.G., Montsion L.M., Westdal K.H., Hall P.A., Orr J.R., Ferguson S.H. \& Marcoux M. 2017. Estimated abundance of the western Hudson Bay beluga stock from the 2015 visual and photographic aerial survey. Canadian Science Advisory Secretariat Research Document 2017/061. Ottawa: Fisheries and Oceans Canada.

McCarney P., Cote D., Laing R., Wells N., Roul S., Novaczek E., Colbourne E., Maillet G., Anderson M.R., Denniston M., Wareham V., Neves B., Murphy A., Gullage L., Allard K., Gjerdrum C., Fifield D., Wilhelm S., Janes J., Pretty C., Gullage M., Lawson J., Stenson G., Paquet J., Hedd A. \& Robertson G. 2021. Biophysical and ecological overview of a study area within the Labrador Inuit Settlement Area zone. Canadian Science Advisory Secretariat Research Document 2021/003. Ottawa: Fisheries and Oceans Canada.

McGhee R. 1974. Beluga hunters: an archaeological reconstruction of the history and culture of the Mackenzie Delta Kittygaryumuit. Newfoundland Social and Economic Studies 13. St. John's, NL: Memorial University of Newfoundland.

Meehan R.H., Belikov S., Desportes G., Ferguson S.H., Kovacs K.M., Laidre K.L., Stenson G.B., Thomas P.O., Ugarte F. \& Vongraven D. 2017. Marine mammals. In: State of the Arctic marine biodiversity report. Pp. 149-173. Akureyri: Conservation of Arctic Flora and Fauna International Secretariat.

Meltofte H. (ed.) 2013. Arctic biodiversity assessment. Status and trends in Arctic biodiversity. Akureyri, Iceland: Conservation of Arctic Flora and Fauna.

Moore R.C., Loseto L., Noel M., Etemadifar A., Brewster J.D., MacPhee S., Bendell L. \& Ross P.S. 2020. Microplastics in beluga whales (Delphinapterus leucas) from the eastern Beaufort Sea. Marine Pollution Bulletin 150, article no. 110723, doi: 10.1016/j.marpolbul.2019.110723.

Mosnier A., Hammill M., Turgeon S. \& Postma L. 2017. Updated analysis of genetic mixing among beluga stocks in the Nunavik marine region and Belcher Islands area: information for population models and harvest allocation. Canadian Science Advisory Secretariat Research Document 2017/016. Ottawa: Fisheries and Oceans Canada.

Mymrin N.I., the Communities of Novoe Chaplino, Sireniki, Uelen, and Yanrakinnot \& Huntington H.P. 1999. Traditional Knowledge of the ecology of beluga whales (Delphinapterus leucas) in the northern Bering Sea, Chukotka, Russia. Arctic, 62-70, doi: 10.14430/arctic910.

NAMMCO 2018. Report of the NAMMCO global review of monodontids, 13-16 March 2017, Hillerød, Denmark. Tromsø, Norway: North Atlantic Marine Mammal Commission.

NAMMCO 2021. Beluga. North Atlantic Marine Mammal Commission. Accessed on the internet at https://nammco. no/topics/beluga/ on 31 August 2021.

Napayok J. 2018. NWMB 2018 hearing on WHB polar bears total allowable harvest harvest modification. Transcript accessed on the internet at https://www.nwmb.com/ en/public-hearings-a-meetings/public-hearings-1/2018/ western-hudson-bay-polar-bear-modification-of-the-to- 
tal-allowable-harvest-in-person-public-hearing/ nwmb-relevant-documents-35/7494-2017-whb-polarbear-hearing-transcript/file on 19 October 2021.

Nielsen O., Burek-Huntington K.A., Loseto L.L., Morell M. \& Romero C.H. 2018. Alphaherpesvirus: isolation, identification, partial characterisation, associated pathologic findings and epidemiology in beluga whales (Delphinapterus leucas) in Alaska and Arctic Canada. Arctic Science 4, 338-357, doi: 10.1139/as-2017-0043.

NOAA Fisheries 2021. Beluga whale. National Oceanic and Atmospheric Administration Fisheries. Accessed on the internet at https://www.fisheries.noaa.gov/species/beluga-whale\#overview on 19 October 2021.

Noel M., Stern G.A. \& Loseto L.L. 2018. Legacy contaminants in the eastern Beaufort Sea beluga whales (Delphinapterus leucas): are temporal trends reflecting regulations? Arctic Science 4, 358-372, doi: 10.1139/as-2017-0049.

Norton P. \& Harwood L.A. 1986. Distribution, abundance and behavior of white whale in Mackenzie Estuary. Report 036. Ottawa: Environmental Studies Revolving Funds.

Nursey-Bray M., Marsh H. \& Ross H. 2010. Exploring discourses in environmental decision making: an Indigenous hunting case study. Society $\theta$ Natural Resources 23, 366-382, doi: $10.1080 / 08941920903468621$.

Obed N. 2016. Free, prior $\&$ informed consent and the future of Inuit self-determination. Northern Public Affairs 4, 38-4l.

O'Corry-Crowe G.M., Suydam R.S., Rosenberg A., Frost K.J. \& Dizon A.E. 1997. Phylogeography, population structure, and dispersal patterns of the beluga whale, Delphinapterus leucas, in the western Nearctic revealed by mitochondrial DNA. Molecular Ecology 6, 955-970, doi: 10.1046/j.1365-294X.1997.00267.X.

Ostertag S., Loseto L.L., Snow K., Lam J., Hynes K. \& Gillman V. 2018. "That's how we know they're healthy". The inclusions of Indigenous Knowledge in beluga health monitoring in the Inuvialuit Settlement Region. Arctic Science 4, 292-320, doi 10.1139/as-2017-0050.

Palsbøll P.J., Heide-Jørgensen M.P. \& Bérubé M. 2002. Analysis of mitochondrial control region nucleotide sequences from Baffin Bay belugas (Delphinapterus leucas): detecting pods or sub-populations? NAMMCO Scientific Publications 4, 39-50, doi: 10.7557/3.2836.

Pearce T.D., Ford J.D., Laidler G.J., Smit B., Duerden R., Allarut M., Andrachuk M., Baryluk S., Dialla A., Elee P., Goose A., Ikummaq T., Joamie E., Kataoyak F., Loring E., Meakin S., Nickels S., Shappa K., Shirley J. \& Wandel J. 2009. Community collaboration and climate change research in the Canadian Arctic. Polar Research 28, 10-27, doi: 10.1111/j.1751-8369.2008.00094.x.

Pearce T., Wright H., Notaina R., Kudlak A., Smit B., Ford J.D. \& Furgal C. 2011. Transmission of environmental knowledge and land skills among Inuit men in Ulukhaktok, Northwest Territories, Canada. Human Ecology 39, 271288, doi: 10.1007/s10745-01 1-9403-1.

Prochukotku.ru. 2020a. Bolee tysjači moržej smogut dobyt' morzveroboi Čukotki v etom godu. (More than a thousand walrus can be caught this year.) Accessed on the internet at https://prochukotku.ru/20200120/10075.html on 31 August 2021.
Prochukotku.ru. 2020b. Kvoty na dobyču kitov raspredelili na Čukotke. (Whale quotas distributed in Chukotka.) Accessed on the internet at https://prochukotku.ru/news/ actual/kvoty_na_dobychu_kitov_raspredelili_na_chukotke_10655/ on 31 August 2021.

Reeves R.R. \& Mitchell E. 1987. History of white whale (Delphinapterus leucas) exploitation in eastern Hudson Bay and James Bay. Canadian Special Publications on Fisheries and Aquatic Sciences 95. Ottawa: Department of Fisheries and Oceans.

Richard P.R., Heide-Jørgensen M.P., Orr J.R., Dietz R. \& Smith T.G. 2001. Summer and autumn movements and habitat use by belugas in the Canadian High Arctic and adjacent areas. Arctic 54, 207-222, doi: 10.14430/arctic782.

Richard P.R. \& Pike D.G. 1993. Small whale co-management in the eastern Canadian Arctic: a case history and analysis. Arctic 46, 138-143, doi: 10.14430/arcticl335.

Scharffenberg K., Whalen D., MacPhee S., Marcoux M., Iacozza J., Davoren G. \& Loseto L. 2020. Oceanographic, ecological, and socio-economic impacts of an unusual summer storm in the Mackenzie Estuary. Arctic Science 6, 62-76, doi: 10.1139/as-2018-0029.

Sejersen F. 2001. Hunting and management of beluga whales (Delphinapterus leucas) in Greenland: changing strategies to cope with new national and local interests. Arctic 54, 431-443, doi: 10.14430/arctic800.

Sharma R., Loseto L.L., Ostertag S.K., Tomaselli M., Bredtmann M.C., Crill C., Rodriquez-Pinacho C., Schultz D., Jung D., Shrethsa K., Jindal P. \& Jenkins E.J. 2018. Qualitative risk assessment of impact of Toxoplasma gondii on health of beluga whales, Delphinapterus leucas from the eastern Beaufort Sea, Northwest Territories. Arctic Science 4, 321-337, doi: 10.1139/as-2017-0037.

Smith A.J., Higdon J.W., Richard P., Orr J., Bernhardt W. \& Ferguson S.H. 2017. Beluga whale summer habitat associations in the Nelson River estuary, western Hudson Bay, Canada. PLoS One 12, e0181045, doi: 10.1371/journal. pone.0181045.

Snook J., Cunsolo A. \& Dale A. 2018. Co-management led research and sharing space on the pathway to Inuit self-determination in research. Northern Public Affairs 6, 52-56.

Snow K., O’Hara S., Esogak D.J., Ostertag S.K. \& Loseto L.L. 2016. Our beluga, fish and environment are changing: Traditional Knowledge study on food resources on Kendall Island in the Inuvialuit Settlement Region. Paper presented at the Arctic Observing Summit, 12-18 March, Fairbanks, AK.

St. Aubin D.J., Smith T.G. \& Geraci J.R. 1990. Seasonal epidermal moult in beluga whales, Delphinapterus leucas. Canadian Journal of Zoology 58, 359-367, doi: 10.1139/ z90-051.

Stevenson M. 1997. Inuit, whalers and cultural persistence: structure in Cumberland Sound and Central Inuit social organization. Oxford: Oxford University Press.

Stewart D.B. 2018. Commercial and subsistence catches of beluga whales (Delphinapterus leucas) from Cumberland Sound, Nunavut, 1840-2016. Canadian Technical Report of Fisheries and Aquatic Sciences 3250. Ottawa: Fisheries and Oceans Canada. 
Taylor J.G. 1977. Traditional land use and occupancy by the Labrador Inuit. In C. Brice-Bennett (ed.) 1977. Our footprints are everywhere: Inuit land use and occupancy in Labrador. Pp. 49-58. Nain, NL: Labrador Inuit Association.

Taylor J.G. \& Taylor H.R. 1977. Inuit land use and occupancy in the Okak region, 1776-1830. In C. Brice-Bennett (ed.) 1977. Our footprints are everywhere: Inuit land use and occupancy in Labrador. Pp. 59-82. Nain, NL: Labrador Inuit Association.

Thompson L.A., Spoon T.R., Goertz C.E.C., Hobbs R.C. $\&$ Romano T.A. 2014. Blow collection as a non-invasive method for measuring cortisol in the beluga (Delphinapterus leucas). PLoS One 9, el14062, doi: 10.1371/ journal.pone.0114062.

Thomsen M.L. 1993. Local knowledge of the distribution, biology, and hunting of beluga and narwhal: a survey among Inuit hunters in west and north Greenland. Nuuk, Greenland: Greenland Hunters' and Fishermen's Association, Greenland Home Rule Authorities, and Inuit Circumpolar Conference.

Turgeon J., Duchesne P., Colbeck G.J., Postma L.D. \& Hammill M.O. 2012. Spatiotemporal segregation among summer stocks of beluga (Delphinapterus leucas) despite nuclear gene flow: implication for the endangered belugas in eastern Hudson Bay (Canada). Conservation Genetics 13, 419-433, doi: 10.1007/s10592-011-0294-x.

Tyrrell M. 2007a. Quaqtarmiut and beluga whales: knowledge, practice and the impact of beluga whale management. Cambridge, UK: Scott Polar Research Institute.

Tyrrell M. 2007b. Sentient beings and wildlife resources: Inuit, beluga whales and management regimes in the
Canadian Arctic. Human Ecology 35, 575-586, doi: 10.1007/ s10745-006-9105-2M.

Tyrrell M. 2008. Nunavik Inuit perspectives on beluga whale management in the Canadian Arctic. Human Organization 67, 322-334, doi: 10.17730/humo.67.3.47826252k0623352.

Waugh D., Pearce T., Ostertag S., Collings P. \& Loseto L. 2018. Inuvialuit Traditional Ecological Knowledge of beluga whale (Delphinapterus leucas) under changing climatic conditions in Tuktoyaktuk, NT. Arctic Science 4, 242-258, doi: 10.1139/as-2017-0034.

Wein E., Freeman M. \& Makus J. 1996. Use of and preference for traditional foods among the Belcher Island Inuit. Arctic 49, 256-264, doi: 10.14430/arcticl201.

Westdal K.H., Davies J., MacPherson A., Orr J. \& Ferguson S.H. 2016. Behavioural changes in belugas (Delphinapterus leucas) during a killer whale (Orcinus orca) attack in southwest Hudson Bay. Canadian Field-Naturalist 130, 315-319, doi: $10.22621 / \mathrm{cfn} . v 130 \mathrm{i} 4.1925$.

Worden E., Pearce T., Gruben M., Ross D., Kowana C. \& Loseto L. 2020. Social-ecological changes and implications for understanding the declining beluga whale (Delphinapterus leucas) harvest in Aklavik, NT. Arctic Science 6, 229-246, doi: 10.1139/AS-2019-0027.

Woshner V.M., O'Hara T.M., Eurell J.A., Wallig M.A., Bratton G.R., Suydam R.S. \& Beasley V.R. 2002. Distribution of inorganic mercury in liver and kidney of beluga and bowhead whales through autometallographic development of light microscopic tissue sections. Toxicologic Pathology 30, 209-215, doi: 10.1080/019262302753559542. 